\title{
REGIONAL DISPARITIES OF INCOME SITUATION AMONG RURAL HOUSEHOLDS IN THE CONTEXT OF THE COHESION POLICY IN POLAND
}

\author{
Andrzej Wołoszyn, $\mathrm{Msc}^{1}$; Romana Głowicka-Wołoszyn, $\mathrm{PhD}^{2}$; \\ Joanna Stanisławska, $\mathrm{PhD}^{3}$; Teresa Oliveira, PhD, Assistant Professor ${ }^{4}$ \\ 1, 2, 3 Faculty of Economics and Social Sciences, Poznań University of Life Sciences \\ ${ }^{4}$ Departamento de Cięncias e Tecnologia, Universidade Aberta
}

\begin{abstract}
The aim of the study was to assess regional income disparities among rural households in Poland in 2005, 2010 and 2015. Simultaneous analysis of changes in affluence and its inequality allowed for a deeper look at the convergence processes in the context of the cohesion policy. The research drew on microdata from the Household Budget Surveys conducted by the Central Statistical Office (GUS). Household income situation or its affluence was proxied by total expenditure. Between 2005 and 2015, despite rising affluence and falling overall inequality, the divergence processes were found to prevail.
\end{abstract}

Keywords: household income, household affluence, income inequality, rural households JEL codes: D31, D63, R2

\section{INTRODUCTION}

One by one the countryside embraces households attracted to the rustic but reluctant to give up the urban lifestyle. What they seek are rewards of living just outside the city: lower costs, cleaner air, lack of noise. The country now, especially within the reach of a large metropolis, has become a mix of agricultural and non-agricultural households, following major demographic changes, such as positive net migration and better age structure than in the cities
(Łącka 2017; Stanisławska and Głowicka-Wołoszyn 2017). Also, between 2007-2014 employment in rural areas fell notably for agriculture and rose for industry, construction and services (Łącka, 2017). These changes contributed to the improvement of the households income situation - still though, the place of residence 'remains a discriminating factor of the level, dynamics and structure of household income and expenditure' (GUS, 2010).

Poland's accession to the EU provided an important stimulus to reduce inequalities in social and eco-

${ }^{1}$ Corresponding author: Wojska Polskiego 28,60-637 Poznań, Poland, andrzej.woloszyn@up.poznan.pl, tel. +4861 8466185

${ }^{2}$ Corresponding author: Wojska Polskiego 28,60-637 Poznań, Poland, roma@up.poznan.pl,+486 8466185

${ }^{3}$ Corresponding author: Wojska Polskiego 28,60-637 Poznań, Poland, stanislawska@up.poznan.pl, +4861 8487118

${ }^{4}$ Corresponding author: Rua Braamcamp 90, 1250-052 Lisboa, Portugal, teresa.oliveira@uab.pt, +351 213916300 
nomic development, promising improvement of the income situation also to rural households (Kozera, Stanisławska and Wysocki, 2014). Behind the promise stood various EU programs, such as the Common Agricultural Policy and the Cohesion Policy. The average real income of farmers households has in fact been rising, and markedly so, both through direct payments and as a result of increases in agricultural prices and production coupled with real decrease in expenditures (GUS, 2010). This positive trend notwithstanding, low income level of many rural households still persists due as it seems to regional divides that manifest themselves in unequal access to education, labour market, and social and physical infrastructure. Such setback hinders the progress towards a socioeconomic cohesion, especially in its territorial aspect, which is the main objective of the Strategy for Responsible Development adopted in 2017 by the Polish government. Its 2020 objectives include: 'increasing the average household gross disposable income per capita to $76-80 \%$ of EU average' and reducing the income disparities between regions (Resolution No 8 of the Council of Ministers, 2017). Monitoring of regional rural household income inequalities is an important element of each country's cohesion policy. It helps policy makers recognize potential threats to the accomplishment of social and economic objectives, and predict the scope and character of negative consequences of their failure. Such failures often affect underdeveloped regions more deeply and range from mass migrations and ensuing population aging, through worsening investment climate, to social apathy paired with prevailing entitlement attitudes.

The aim of the empirical research was to diagnose changes in the income situation of rural households across the regions of Poland and between 2005, 2010 and 2015, including the level of income and its inequality.

\section{MATERIALS AND METHODS}

The research drew on microdata from the Household Budget Surveys conducted by the Central Statistical Office (GUS) in 2005, 2010 and 2015, that examined respectively 34,$767 ; 37,412$ and 37,148 households, roughly $42 \%$ of which were rural.

In the study, the income (or affluence) was proxied by the level of spending. According to Kot (2003) affluence of Polish households is better reflected by total expenditures, being less prone to deliberate misclosures than net disposable income. Brzeziński (2002) also supports this view citing Slesnick's (1998) 'consumption smoothing hypothesis', that equates consumption affluence with Friedman's 'permanent income' affluence. The last idea is especially important in the case of farmers households, were monthly disposable income seasonality can be extreme (cf. Wołoszyn, 2013). To compare households with different demographic composition, modified OECD scale was used (Dudek, 2011) arriving finally at real (in 2015 prices $^{5}$ ) equivalent expenditures ${ }^{6}$ as the measure of household affluence or income ${ }^{7}$. The two last expressions will be used interchangeably throughout the paper.

Income inequality of rural households in Polish provinces was assessed with Gini coefficient (Cowell, 2009; Panek 2011; Kot, 2012), the most popular index of inequality, that ranges between 0 (for perfectly equal distribution) and 1 (for perfectly unequal one):

$$
G=\frac{1}{2 \mu} \frac{\sum_{i} \sum_{j}\left|y_{i}-y_{j}\right|}{N^{2}}
$$

where:

$N$ - number of households;

$\mu$ - average expenditures;

$y_{i}, y_{j}$ - expenditures of the $i$-th and $j$-th households.

\footnotetext{
${ }^{5}$ The calculations were based on CPI indices from Roczne wskaźniki (GUS, 2017).

${ }^{6}$ The exact classification of household expenditures covering expenditures on consumer goods and services and other expenses is presented on pp. 62-63 of Metodologia Badania Budżetów Gospodarstw Domowych (GUS, 2011).

${ }^{7}$ One should bear in mind that inequality calculated from this measure will be smaller than from the theoretical 'permanent income', MPC being lower for the richer than for the poorer households.
} 


\section{RESULTS}

In 2005 the most affluent were the rural households of Opolskie, Lubuskie and Śląskie (Table 1). They averaged, by real equivalent expenditures, PLN 1,365; 1,322 and 1,211 respectively, higher than the average for Polish rural households by 25, 21 and $11 \%$. Conversely, the northern provinces of Warmińsko-Mazurskie, Zachodniopomorskie and Pomorskie recorded the lowest levels of affluence, between PLN 964 and 970 , that were all roughly $11 \%$ below the national average.

Economic prosperity, continuous rise of household income nationwide (GUS, 2010), Poland's accession to the EU with increases in agricultural prices, subsidies and production (Kozera and Wysocki, 2014) all translated into significant improvement of rural households income situation between 2005 and 2010 (by $28.4 \%$ to the level of PLN 1,400). The largest increases were recorded in the following provinces: Pomorskie (by as much as $45.5 \%$ ), Mazowieckie (by $44.2 \%$ ) and Kujawsko-Pomorskie (by 42.9\%). In 2011 all Polish households felt clear signs of economic downturn: it was the first year since 2004 when year-to-year disposable income fell down (GUS, 2011). The ensuing period of depression and slow recovery, up until 2015, saw reduction of rural households affluence levels in six provinces (by 1$-4 \%$ ) and only slight growth in the remaining ones (by 1-9\%), except in Zachodniopomorskie, where an increase by $14 \%$ was recorded. Overall rural household affluence growth between 2010 and 2015 was small - of only $2 \%$.

In 2015 the rural affluence level averaged PLN 1,428 and was less unequal across provinces than in 2005. The highest levels were recorded in Śląskie, Mazowieckie and Dolnośląskie (respectively 15.2, 11.8 and $10.9 \%$ higher than the national rural household average), while the lowest in Warmińsko-Mazurskie and Świętokrzyskie (respectively 14 and 11\% lower) - Table 1.

Income inequality among all rural households, determined from equivalent expenditures and measured by the Gini coefficient, was 0.299 in 2005 (Table 2), slightly lower than for all households, which was 0.320 (Wołoszyn, 2013). The period between 2005 and 2015 witnessed reductions in the rural inequality both nationwide and province-wide, with the exception of Świętokrzyskie (Table 2).

All in all, between 2005 and 2015 a 31\% increase in overall affluence of rural households (Table 1) was accompanied by a decrease in income inequality by 0.011 (Table 2), which might suggest unfolding of some convergence processes. However, in-depth analysis of the rural affluence of individual provinces does not give such an unambiguous assessment of changes.

A particularly high increase in affluence was recorded in the following provinces: Sląskie (by $35.8 \%$ ), Mazowieckie (by 40.5\%), Dolnośląskie (by $50.6 \%$ ), Pomorskie (41.0\%), Kujawsko-Pomorskie (41.5\%) and Zachodniopomorskie (by 45.9\%). However, only in the cases of Kujawsko-Pomorskie, Zachodniopomorskie and Pomorskie the increase may be considered as cohesion enhancing, as their affluence in 2005 was below the national average by $8 \%$ and $11 \%$ (the gap having shrunk in 2015 to just $0.4 \%$ and $1.5 \%$ respectively for $\mathrm{Ku}-$ jawsko-Pomorskie and Zachodniopomorskie and to $4.0 \%$ for Pomorskie). Increases in the first three provinces, where in 2005 affluence had already been well above the average, were clearly cohesion weakening. The reason for this is rather simple: the existence of three strong and expansive metropolises, where advancing suburbanization sprawls onto adjacent rural communes. On the other hand, small affluence increase in Lubuskie and Opolskie provinces (that had the highest initial affluence in 2005), translated into sharp falls of relative affluence (to 104.6 and $108.3 \%$, respectively), that were seemingly cohesion enhancing. It is worth noting however, that slow growth in Lubuskie and Opolskie was largely due to mass emigration, drop in birth rates and rapid population ageing (Bartkowiak-Bakun and Standard, 2014; Kubiciel-Lodzińska and Mąkolska-Frankowska, 2016). It is unclear how durable is the current slowdown, but if the trend continues, the rural affluence of these provinces will drop below the national average, reversing the apparently good cohesion indicators.

Figure 1 presents the affluence of rural households in 2005, 2010 and 2015 together with its 
Table 1. Real and relative (in relation to the average of rural households in Poland) affluence level of rural households by province and its changes between 2005, 2010 and 2015

\begin{tabular}{|c|c|c|c|c|c|c|c|c|}
\hline \multirow{2}{*}{ Province } & \multicolumn{3}{|c|}{$\begin{array}{c}\text { Affluence } \\
\text { (PLN/equivalent person) }\end{array}$} & \multicolumn{2}{|c|}{$\begin{array}{l}\text { Affluence changes } \\
(\text { const. }=2005)(\%)\end{array}$} & \multicolumn{3}{|c|}{$\begin{array}{c}\text { Relative affluence }(\text { Poland }=100) \\
(\%)\end{array}$} \\
\hline & 2005 & 2010 & 2015 & 2010 & 2015 & 2005 & 2010 & 2015 \\
\hline Dolnośląskie & 1052 & 1452 & 1584 & 38.0 & 50.6 & 96.5 & 103.7 & 110.9 \\
\hline Kujawsko-Pomorskie & 1006 & 1438 & 1423 & 42.9 & 41.5 & 92.3 & 102.7 & 99.6 \\
\hline Lubelskie & 1092 & 1242 & 1334 & 13.7 & 22.2 & 100.2 & 88.7 & 93.4 \\
\hline Lubuskie & 1322 & 1470 & 1494 & 11.2 & 13.0 & 121.3 & 105.0 & 104.6 \\
\hline Łódzkie & 1135 & 1423 & 1506 & 25.4 & 32.7 & 104.1 & 101.6 & 105.5 \\
\hline Małopolskie & 1102 & 1344 & 1369 & 22.0 & 24.2 & 101.1 & 96.0 & 95.9 \\
\hline Mazowieckie & 1137 & 1640 & 1597 & 44.2 & 40.5 & 104.3 & 117.1 & 111.8 \\
\hline Opolskie & 1365 & 1586 & 1546 & 16.2 & 13.3 & 125.2 & 113.3 & 108.3 \\
\hline Podkarpackie & 1039 & 1270 & 1286 & 22.2 & 23.8 & 95.3 & 90.7 & 90.1 \\
\hline Podlaskie & 1109 & 1250 & 1327 & 12.7 & 19.7 & 101.7 & 89.3 & 92.9 \\
\hline Pomorskie & 970 & 1411 & 1368 & 45.5 & 41.0 & 89.0 & 100.8 & 95.8 \\
\hline Śląskie & 1211 & 1547 & 1645 & 27.7 & 35.8 & 111.1 & 110.5 & 115.2 \\
\hline Świętokrzyskie & 997 & 1309 & 1269 & 31.3 & 27.3 & 91.5 & 93.5 & 88.9 \\
\hline Wielkopolskie & 1069 & 1370 & 1387 & 28.2 & 29.7 & 98.1 & 97.9 & 97.1 \\
\hline Warmińsko-Mazurskie & 964 & 1272 & 1226 & 32.0 & 27.2 & 88.4 & 90.9 & 85.9 \\
\hline Zachodniopomorskie & 964 & 1233 & 1406 & 27.9 & 45.9 & 88.4 & 88.1 & 98.5 \\
\hline Poland & 1090 & 1400 & 1428 & 28.4 & 31.0 & 100.0 & 100.0 & 100.0 \\
\hline
\end{tabular}

Source: own calculations based microdata from House Budget Survey $(2005,2010,2015)$.

Table 2. Income inequality of rural households by province and its changes between 2005, 2010 and 2015

\begin{tabular}{|l|c|c|c|c|c|}
\hline \multirow{2}{*}{ Province } & \multicolumn{3}{|c|}{ Gini $\cdot 100$} & \multicolumn{2}{c|}{ Gini changes $\cdot 100$ (const.=2005) } \\
\cline { 2 - 6 } & 2005 & 2010 & 2015 & 2010 & 2015 \\
\hline Dolnośląskie & 31.4 & 31.4 & 29.6 & 0.0 & -1.8 \\
\hline Kujawsko-Pomorskie & 28.1 & 30.0 & 28.0 & 1.9 & -0.1 \\
\hline Lubelskie & 29.2 & 30.5 & 28.0 & 1.3 & -1.2 \\
\hline Lubuskie & 33.1 & 27.8 & 26.8 & -5.3 & -6.3 \\
\hline Lódzkie & 28.5 & 30.1 & 28.2 & 1.6 & -0.3 \\
\hline Małopolskie & 28.8 & 25.6 & 28.2 & -3.2 & -0.6 \\
\hline Mazowieckie & 30.2 & 33.9 & 28.5 & 3.7 & -1.7 \\
\hline Opolskie & 30.1 & 29.6 & 28.3 & -0.5 & -1.8 \\
\hline Podkarpackie & 27.4 & 24.7 & 27.4 & -2.7 & 0.0 \\
\hline Podlaskie & 31.8 & 29.5 & 28.8 & -2.3 & -3.0 \\
\hline Pomorskie & 30.5 & 33.8 & 29.5 & 3.3 & -1.0 \\
\hline Śląskie & 29.6 & 30.7 & 28.7 & 1.1 & -0.9 \\
\hline Świętokrzyskie & 27.1 & 30.5 & 28.8 & 3.4 & 1.7 \\
\hline Wielkopolskie & 30.8 & 27.4 & 28.9 & -3.4 & -1.9 \\
\hline Warmińsko-Mazurskie & 30.9 & 32.5 & 28.8 & 1.6 & -2.1 \\
\hline Zachodniopomorskie & 28.2 & 27.3 & 26.0 & -0.9 & -2.2 \\
\hline Poland & 29.9 & 30.1 & 28.8 & 0.2 & -1.1 \\
\hline So & & & & & \\
\hline
\end{tabular}

Source: own calculations based microdata from House Budget Survey $(2005,2010,2015)$. 


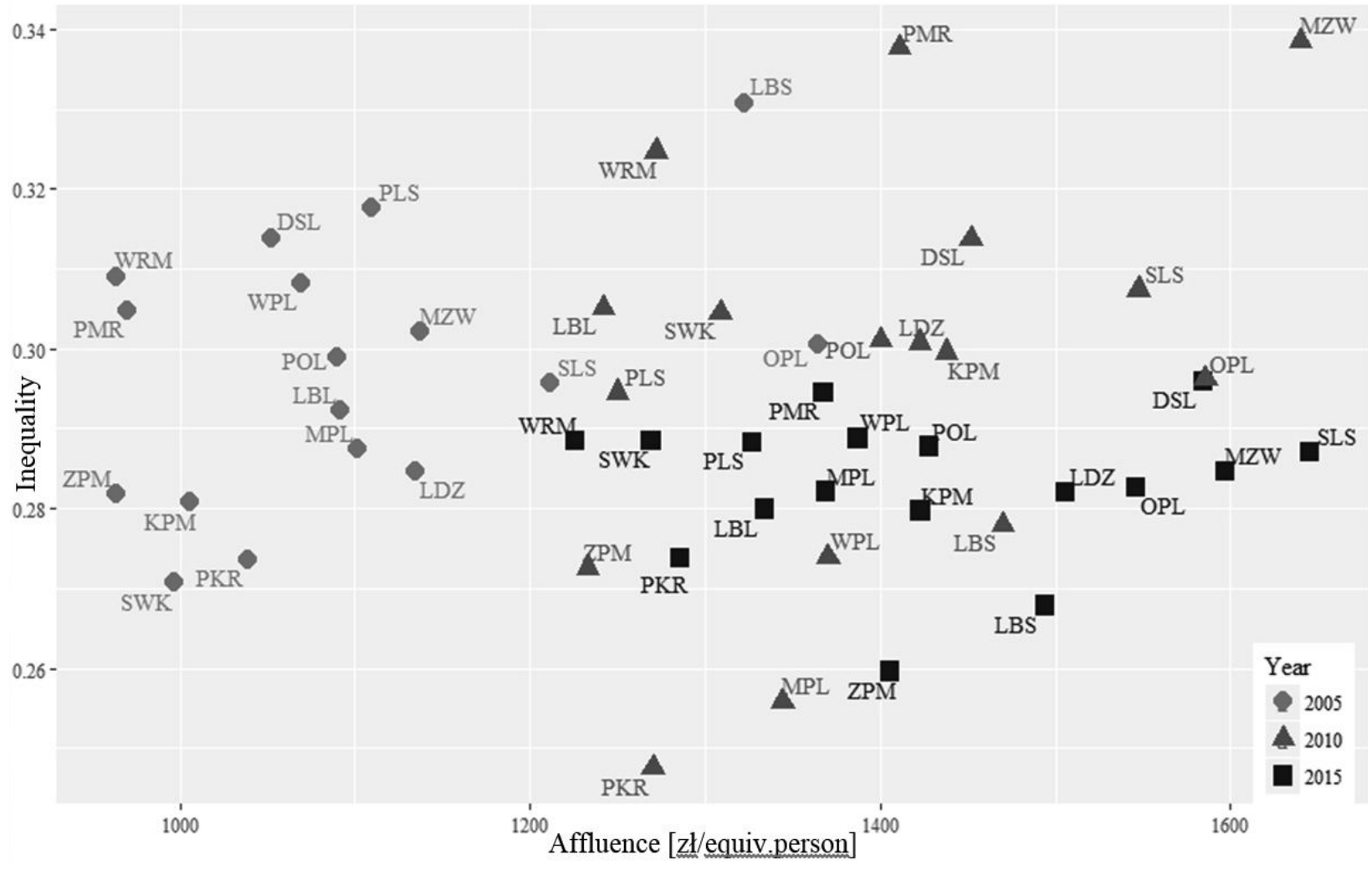

Province designations: DSL - Dolnośląskie, KPM - Kujawsko-Pomorskie, LBL - Lubelskie, LBS - Lubuskie, LDZ - Łódzkie, MPL - Małopolskie, MZW - Mazowieckie, OPL - Opolskie, PKR - Podkarpackie, PLS - Podlaskie, PMR - Pomorskie, SLS - Śląskie, SWK - Świętokrzyskie, WPL - Wielkopolskie, WRM - Warmińsko-Mazurskie, ZPM - Zachodniopomorskie, POL - the whole country.

Figure 1. Affluence and inequality in rural households in Poland in 2005, 2010 and 2015

Source: own calculations based microdata from House Budget Survey (GUS 2005, 2010, 2015).

inequality by provinces, illustrating simultaneously the range of both measures and the changes that happened between the studied years. One can see immediately that diamonds corresponding to provinces in 2005 are placed far to the left of triangles and squares that correspond to provinces in 2010 and 2015. This shows that the significant increase in rural affluence occurred mostly between 2005 and 2010. Also, the squares keep rather to the lower right side of the chart, while triangles to the upper right side (although with much overlap), demonstrating slow affluence growth coupled with reduction in its inequality that took place between 2010 and 2015 for most provinces.

\section{CONCLUSIONS}

The research on the income situation of rural households in Poland found a significant affluence increase in all provinces between 2005 and 2010, concurrent with a slight rise of affluence inequality in most provinces. Conversely, the period between 2010 and 2015 saw only a minor affluence growth, but generally with a pronounced drop in inequality.

In some provinces convergence processes were observed: rural affluence levelled towards the national average and income inequality decreased. I would be impossible however, to claim these changes were the result of a targeted cohesion policy. Only in the 
case of three provinces, Kujawsko-Pomorskie Zachodniopomorskie and Pomorskie, can one speak of simple convergence processes - improvement of the relative income situation, approaching affluence levels of the national average and a decrease in income inequalities. This is not exactly the case of Opolskie and Lubuskie. These provinces formally exhibited outward signs of cohesive processes, having in 2005 lead the ranking of rural affluence and moving down in 2015 , but these changes were most likely a result of a profound demographic crisis, and not of a more dynamic growth in the remaining provinces.

On the other hand, changes in two provinces: Śląskie and Mazowieckie were clearly of divergent character, and likely the result of influence exerted by their large urban centres. That influence was channelled through suburbanization and multifunctional development of metropolitan rural hinterlands. All in all, the study did find some evidence of ongoing convergence processes, but restricted or hardly tenable. Divergence processes, on the other hand, seemed to be rising on sounder foundations and manifested themselves far more clearly.

\section{REFERENCES}

1. Bartkowiak-Bakun, N., Standar A. (2014). Zróżnicowanie sytuacji demograficznej obszarów wiejskich pogranicza zachodniego [The diversity of the demographic situation in rural areas of the western borderland]. Roczniki Naukowe SERiA, 16 (6), pp. 27-31.

2. Brzeziński, M. (2002). Wpływ nierówności dochodowej na dobrobyt społeczny w Polsce w latach 1987-1997 [Impact of income inequality on social well-being in Poland 1987-1997]. Gospodarka Narodowa, 9, pp. 41-60.

3. GUS (2005). Budżety gospodarstw domowych [House Budget Survey]. Dział Wydawnictw Statystycznych, Warszawa.

4. GUS (2010). Budżety gospodarstw domowych [House Budget Survey]. Dział Wydawnictw Statystycznych, Warszawa.

5. GUS (2011). Metodologia Badania Budżetów Gospodarstw Domowych [Methodology of Household Budget Study]. Dział Wydawnictw Statystycznych, Warszawa.

6. GUS (2015). Budżety gospodarstw domowych [House Budget Survey]. Dział Wydawnictw Statystycznych, Warszawa.
7. GUS (2017). Roczne wskaźniki cen towarów i usług konsumpcyjnych od 1950 roku [Annual price indices of consumer goods and services since 1950]. Retrieved from: https://stat.gov.pl/obszary-tematyczne/ ceny-handel/wskazniki-cen/wskazniki-cen-towarow-iuslug-konsumpcyjnych-pot-inflacja-/roczne-wskazniki-cen-towarow-i-uslug-konsumpcyjnych/ [Accessed 150.09.2018].

8. Cowell, F.A. (2009). Measuring Inequality. 3rd ed. Oxford University Press, Oxford.

9. Dudek, H. (2011). Skale ekwiwalentności - estymacja na podstawie kompletnych modeli popytu [Equivalence scales - estimation on the base of complete demand systems]. Wydawnictwo SGGW, Warszawa.

10. Kot, S.M. (2003). Metodologiczne dylematy pomiaru nierówności i dobrobytu [The Methodological Dilemmas of the Measurement of Inequality and Welfare]. Nierówności Społeczne a Wzrost Gospodarczy, 1, pp. 161-179.

11. Kozera, A., Stanisławska, J., Wysocki, F. (2014). Sytuacja finansowa gospodarstw domowych zamieszkujących obszary wiejskie w Polsce po wstapieniu polski do unii europejskiej [The financial situation of households in rural areas in Poland in the context of European integration]. Roczniki Naukowe Ekonomii Rolnictwa i Rozwoju Obszarów Wiejskich, 101 (2), pp. 91-101.

12. Kubiciel-Lodzińska, S., Mąkolska-Frankowska I. (2016). Stabilizacja zasobów pracy w województwie opolskim w kontekście wyzwań demograficznych - podejmowane działania [Stabilization of employees resources in Opolskie voivodeship in the context of demographic challenge - undertaken activities]. Studia Ekonomiczne. Zeszyty Naukowe Uniwersytetu Ekonomicznego w Katowicach, 258, pp. 121-134.

13. Łącka, I. (2017). Sytuacja dochodowa wiejskich gospodarstw domowych w Polsce w latach 2007-2014 $i$ jej skutki [Income situation of rural households in Poland between 2007 and 2014 and its effects]. Problemy Drobnych Gospodarstw Rolnych - Problems of Small Agricultural Holdings, 1, pp. 29-42.

14. Panek, T. (2011). Ubóstwo, wykluczenie społeczne i nierówności, Teoria i praktyka pomiaru [Poverty, social exclusion and inequality, Measurement theory and practice]. Oficyna Wydawnicza SGH, Warszawa.

15. Slesnick, D.T. (1998). Empirical Approaches to the Measurement of Welfare. Journal of Economic Literature, 36, pp. 2108-2165.

16. Stanisławska, J., Głowicka-Wołoszyn, R. (2017). Przemiany demograficzne na obszarach wiejskich woje- 
Proceedings of the 2018 International Scientific Conference 'Economic Sciences for Agribusiness and Rural Economy' No 1, Warsaw, 7-8 June 2018, pp. 194-200

wództwa wielkopolskiego w latach 2005-2015 [Demographic changes in the rural areas of the Wielkopolska province in 2005-2015]. Roczniki Naukowe SERiA, 19 (1), pp. 170-175.

17. Uchwała nr 8 Rady Ministrów z dnia 14 lutego 2017 r. w sprawie przyjęcia Strategii na rzecz Odpowiedzialnego Rozwoju do roku 2020 (z perspektywą do 2030 r.) [Resolution No 8 of the Council of Ministers of 14 February 2017 on adopting the Strategy for responsible de- velopment until 2020 (with a perspective until 2030)]. Official Journal of Poland 2017, item 260.

18. Wołoszyn, A. (2013). Nierówności dochodowe w gospodarstwach domowych rolników na tle innych grup społeczno-ekonomicznych w Polsce w latach 2005 i 2010 [Income inequality among farmer households against other socio-economic groups in Poland in 2005 and 2010]. Roczniki Naukowe SERiA, 15 (6), pp. 313-319. 